\title{
CONSERVATION STATUS AND STRATEGIES FOR THE PRESERVATION OF ORCHIDS IN THE SOCONUSCO REGION OF SOUTHEAST MEXICO
}

\author{
AnNe DAMON \\ Department of Biodiversity Conservation, El Colegio de la Frontera Sur (ECOSUR), \\ Carretera Antiguo Aeropuerto km. 2.5, Tapachula, Chiapas, México \\ adamon@ecosur.mx
}

\begin{abstract}
A total of 320 orchid species are registered for the biodiverse region of Soconusco in the southeastern tip of Mexico. Given certain social, political, and legal limitations, the most productive strategy for preserving and restoring populations of the various species in danger of extinction, endemic, and over-exploited has been to work directly, intensively, and long-term with communities situated within or near to the few remaining hot spots of orchid diversity and abundance. With the appropriate permits, sustainable orchid cultivation has been established in various communities. We continue with long-term research into key aspects of the biology and ecology of orchids, identification of refuge sites, and modeling of geographical distribution of species.

Resumen. Un total de 320 de orquídeas se han registrado para la región del Soconusco en el extreme sureste de México. Dado los inherentes limitantes sociales, políticos y legales, parece ser que la estratégica más productiva para preservar y restaurar poblaciones de las varias especies en peligro de extinción, endémicas y sobreexplotadas es el trabajo directo, intensivo y a largo plazo con las comunidades ubicadas dentro o cerca de los pocos puntos calientes restantes de diversidad y abundancia de orquídeas. Con los debidos permisos, se han establecido cultivos sustentables de orquídeas en varias comunidades y se continúa con investigaciones a largo plazo sobre aspectos claves de la biología y ecología de las orquídeas, la identificación de sitios de refugio y la modelación de la distribución geográfica de especies.
\end{abstract}

KEY WORDS: modeling of geographic distribution, orchid mycorrhizae (OM), retrospective spatial analysis of pollination, Unit of Environmental Management (UMA)

Soconusco region is situated in the southeastern extreme of Mexico in the state of Chiapas, with the greatest orchid species richness per area in Mexico (Damon 2010). The region possesses highly fertile soils on the coastal plain and a diversity of ecosystems from mangrove swamps, through a variety types of tropical and temperate forest, to alpine dwarf forest on the slopes of the 4092 m-high Tacaná volcano. Of particular importance are the Tacaná - Boquerón biological corridor designated as a priority Terrestrial Region by CONABIO* (RTP*-135) and the three Biosphere Reserves -- Tacaná Volcano, La Encrucijada and El Triunfo (CONANP*).
Constant changes in agricultural priorities and the relatively recent paternalistic strategies, have promoted an increasingly demoralized, passive, and dependent population that now subsists on government aid channeled through a variety of social, economic, and environmental programs, while production, effective land management, and conservation of natural resources continue to deteriorate. Mexico is a wealthy country that could do much to satisfy the basic demands of the population and at the same time promote and support conservation, sustainable exploitation, and legal protection of its rich natural resources. Major problems are corruption and the lack

* GLOSSARY

CONABIO - National Commission for the Knowledge and Use of Biodiversity; CONANP - National Commission of Protected Areas; NOM-ECOL-059 - Legislation for the Protection of Mexican Native Species of Flora and Fauna; OSSSU - Orchid Seed Stores for Sustainable Use; RTP - Priority Terrestrial Region. CONABIO; SEMARNAT - Secretariat for the Environment and Natural Resources. Mexico; UMA - Environmental Management Unit. 
of personnel, funding, training, and commitment to environmental issues.

Within that scenario, the trade in wild species is extensive, largely unregulated and an important and well-defended source of income for many rural peasants, which then feeds into the national and international networks. Unfortunately, although regulation and the identification of vulnerable species exists (NOMECOL-059-2010*), with mechanisms for the issuing of permits for conservation management and sustainable exploitation of endangered species of flora and fauna, in reality most of the permits (UMAs*. SEMARNAT*) are authorized for hunting mammals and birds and there are few UMAs currently set up to commercially exploit plant and animal species that are not edible or huntable. Little has been achieved trying to work within the framework of the law to stop illegal extraction and trade in wild plants and animals or to halt habitat destruction.

The list of orchid species registered for Soconusco includes 320 species (Damon 2010), with several more awaiting identification and the resolution of taxonomic problems. At least 37 species are categorized as vulnerable or in danger of extinction within the NOM-ECOL-051-2010. Various species are endemic, and historic registers indicate that many species have now disappeared from the region. Guarianthe skinneri (Bateman) Dressler \& W.E.Higgins, a once abundant but highly prized species, is now found only in private gardens and a few sites within protected areas and traditional coffee plantations (i.e. those with a diversity of original forest trees as shade).

Strategies for the preservation of orchids in Soconusco or anywhere else must, therefore, take into account social, political, and legal limitations. It appears that the best strategy is to work directly, intensively, and long-term with communities situated within or near the few remaining hot spots of orchid diversity and abundance. This labor-intensive, often frustrating approach depends on volunteers and a constant input of small amounts of money and materials, but it is to be preferred over short-term, government-financed projects that definitely do not work. It is also important to identify the few genuinely interested personnel within the relevant government departments and seek their collaboration for obtaining contacts and permits, in this case for the UMAs and the collection of orchids within protected areas.
The project "Ecology and Sustainable Cultivation of Soconuscan Orchids" (ECOSUR-Tapachula) has set out to make a positive contribution to the preservation of native orchid species. We have identified pollination and mycorrhizal associations as two key areas of research, with training and long-term collaboration with rural communities (Damon 2006) for the sustainable exploitation of local orchids as the only practical activities that might make a difference. The project includes a botanical garden at $80 \mathrm{~m}$ and an orchidarium at $1200 \mathrm{~m}$ for the rescue, conservation, and study of local orchids (and other plants).

In collaboration with personnel from CONANP, two UMAs for the sustainable production of orchids in rural communities in Soconusco have been established with another in process and various other communities interested in participating. The participants start out with a week of introductory training before work begins, which also serves to filter out those who are only there in the hope of financial benefits or are not willing to participate actively. The methods applied in these UMAs involve the rescue of orchid plants found on the ground, on dead and felled trees or pruned branches (e.g. of shade trees in coffee plantations) and their establishment in specially designed galleries. With time and a regime of basic care, these plants are vegetatively reproduced and the divisions planted in suitable sites in traditional coffee plantations, forest fragments, and protected areas. A proportion of the flowers produced will be naturally or hand-pollinated to produce seed for local research and in vitro production in our project laboratory and to contribute to the OSSSU* initiative (Seaton 2011); other flowers will be harvested and processed to make original craft items for sale for the benefit of the producers.

To be able to restore and preserve natural resources we need high-quality information about all aspects of biology, ecology, and refuge sites such as mountain peaks and ravines. In the case of orchids, especially epiphytic species, pollination and mycorrhizal associations are particularly important as they represent the two major bottlenecks in the orchid life cycle (Ackerman \& Zimmerman 1994). We know little about pollination under natural conditions of a majority of the world's epiphytic orchid species, which are often inaccessible in the crowns of tall, tropical forest trees. Many species are rare, with small, widely dispersed 
populations. Direct observation of the flowers of most species yields little information, as pollinator visits are unpredictable, infrequent, and ephemeral. The study of orchid pollination has been dominated by few studies of charismatic, widespread, accessible, and often terrestrial species that may not be representative of the majority. Furthermore, the orchid family is notorious for a diversity of pollination mechanisms, particularly various types of deceit strategies with particularly low pollination rates.

Low-percentage pollination of flowers may be normal, or even strategic, for many epiphytic orchids, and we may advance our understanding further if we rationalize these observations at a metapopulation level. I have devised a technique for studying the pollination of epiphytic orchids without direct observation of pollinators (Damon \& Valle Mora 2008; Pérez-Hernández et al. 2011). This technique is adaptable to any orchid population where all flowering individuals may be observed. First, the precise conditions and spatial distribution of every flower are noted and mapped, followed by mapping fruits as they appear within that arrangement. The conditions noted may include visibility, orientation, height above ground, and the density of flowers at that point to analyze the importance of these parameters for the attraction of pollinators and the successful pollination of individual flowers or aggregations of flowers. The results may indicate pollinator preference for certain conditions, or in the case of deceit mechanisms, the likelihood of achieving pollinator deception within the range of flower presentations offered. However, results obtained with two miniature orchid epiphytes indicate that none of the parameters so far studied has a significant effect (density or aggregation of flowers occasionally has a weak effect) upon the likelihood of a flower being pollinated. I have suggested that, at least for the two species we studied, the pollination of any particular flower may depend on luck or chance, but that every successful pollination event is heavily compensated by the production of thousands or millions of seeds. We hope to continue with basic pollination studies (e.g. Damon et al. 2012) and in particular to develop this retrospective spatial technique, using improved geopositioning, mapping, and modeling techniques to extend it to a metapopulation level. However, recent directives that coffee producers must eliminate all mosses and other epiphytes from the stems and branches of their coffee bushes have resulted in the almost total elimination of the small and miniature orchids that have so successfully adapted to coffee plantations since the end of the nineteenth century when coffee was first introduced into Mexico. As a result, it may now be impossible to continue with this interesting and revealing line of research, which would be impossible to carry out effectively within a forest environment.

The evolution and geographical distribution of Orchidaceae depend not only upon pollinators but also upon their endophytic, mycotrophic symbionts (Waterman \& Bidartondo 2008), apparently involving a specific group of fungi, termed orchid mycorrhizae (OM) which belong to the Rhizoctonia group (Otero et al. 2007). Although it was originally thought that colonization was sporadic and seasonal (Hadley \& Williamson 1972; Lesica \& Antibus 1990), recent studies indicate that a dense and continuous colonization is the norm in tropical orchid species (Rivas et al. 1998; Pereira et al. 2005a). We now have evidence of patterns of evolutionary co-diversification and specificity (Otero et al. 2011), which could indicate that $\mathrm{OM}$ have a role to play in the rarity of many orchid species. However, to the contrary, a study of two European terrestrial species showed that questions of specificity did not determine rarity in those species (Cachapa Bailarote et al. 2012).

We know little about these endophytic mycorrhizal fungi that are implicated in various functions of the orchid plant throughout its life cycle, including seed germination, defense, and nutrition. Orchids can be classified within a continuous spectrum from partial (mixotrophy) to obligate mycotrophy, in which plants depend completely on the fungi for their supply of carbon and nitrogen (Julou et al. 2005). Orchid mycorrhizae have a positive effect on germination (Suárez et al. 2006; Rains et al. 2003), although Arditti (1992), Smith and Read (1997), and Zettler et al. (2003) have suggested reasons to doubt the importance of OM in this process. Studies on the symbiotic, in vitro germination of orchid seeds indicate that, although the seeds may imbibe water and swell in a pre-germinative phase, OM intervene in the process of differentiation and development (Zettler et al. 1998); without them the seeds remain trapped in the pre-germinative phase 
and eventually die (Pereira et al. 2005b). Future work will focus upon the development of in situ symbiotic seed germination techniques, study of the ecological niches of these endophytic fungi, and research into the biochemical pathways that determine the process of recognition between fungus and orchid, invasion of orchid cells by the fungus, and control of the process of the digestion of fungal tissues by the orchid, which effectively functions as a parasite.

We are currently involved in a project to map the geographic distribution of all the species that have been registered within the Soconusco region, which in the initial stages involved collaboration with various institutions in Central America and Colombia (list of participating institutions provided on request; Damon 2012-13). This process has been useful to emphasize which orchid species are rare not only in Soconusco but also throughout their distribution, and also where investment and collaboration are needed to enable completion of vital taxonomic and ecological studies (Costello et al. 2013). The actual and predictive maps of geographical distribution generated will allow the identification of sites suitable for the restoration and conservation of populations, coincidence with pollinators and fungal symbionts, vulnerability to climate change, and much more.

Over the next few years we hope to be able to begin to answer some of the fundamental questions mentioned here, using remaining, common orchid populations, traditional coffee plantations, forest fragments, and protected areas as models (Light \& MacConaill 2011). We hope it is not too late to save the majority of the Orchidaceae and the ecosystems that we and they depend on for future generations (Hirtz 2011).

ACKNOWLEDGMENTS. Thank you to Vincenzo Bertolini for contributing information about mycorrhizal interactions and to collaborators Nelson Pérez Miguel, James Rodriguez Acosta, the orchid producers, owners of the experimental sites, and various graduate and postgraduate students, for their hard work, ideas, and support.

\section{LiTERATURE CITED}

Ackerman, J.D. \& J.K. Zimmerman. 1994. Bottlenecks in the life histories of orchids: resources, pollination, population structure and seedling establishment. Pp.
138-147 in: A.M. Pridgeon (ed.), Proceedings of the 14th World Orchid Conference. HMSO, Edinburgh.

Arditti, J. 1992. Fundamentals of orchid biology. New York, John Wiley \& Sons.

Cachapa Bailarote, B., B. Lievens \& H. Jacquemyn. 2012. Does mycorrhizal specificity affect orchid decline and rarity? Amer. J. Bot. 99: 1655-1665.

Costello, M.J., R.M. May \& N.E. Stork. 2013. Can we name earth's species before they go extinct? Science 339: 413-416.

Damon, A. 2006. Soconusco has a chance to rediscover and protect its disappearing orchids. IUCN. Orchid Specialist Group. Orch. Cons. News 8: 6-13.

Damon, A. 2010. Diversidad y conservación de las orquídeas del corredor biológico Tacaná-Boquerón. Technical report. Project CONACYT Fondos Mixtos, Chiapas CHIS-2006-C06-45802. Mexico.

Damon, A. 2012-2013. Modelación de la distribución geográfica de las orquídeas del Soconusco. Project CONABIO JM061, Mexico.

Damon, A., F. Hernández-Ramírez, L. Riggi, R. Veerspor, V. Bertolini, A. Wiles, A. Burns \& M. Lennartz-Walker. 2012. Pollination of euglossinophylic epiphytic orchids in agroecosystems and forest fragments in southeast Mexico. Eur. J. Environ. Sci. 2: 5-14.

Damon, A. \& J. Valle-Mora. 2008. Retrospective spatial analysis of the pollination of two miniature epiphytic orchids with different pollination strategies in a coffee plantation in Soconusco, Chiapas, Mexico. Bot. J. Linn. Soc. 158: 448-459.

Hadley, G. \& B. Williamson. 1972. Features of mycorrhizal infection in some Malayan orchids. New Phytol. 71: 1111-1118.

Hirtz, A. 2011. What will be left of the primary forests in Ecuador? Lankesteriana 11: 265-268.

Julou, T., B. Burghardt, G. Gebauer, D. Berveiller, C. Damesin \& M.A. Selosse. 2005. Mixotrophy in orchids: insights from a comparative study of green individuals and nonphotosynthetic individuals of Cephalanthera damasonium. New Phytol. 166: 639-653.

Lesica, P. \& R.K. Antibus. 1990. The occurrence of mycorrhizae in vascular epiphytes of two Costa Rican rain forests. Biotropica 22: 250-258.

Light, M. \& M. MacConaill. 2011. The role of common orchids in appreciating the complexity of biodiversity conservation. Lankesteriana 11: 293-300.

Otero, J.T., N. Flanagan, A. Herre, J. Ackerman \& P. Bayman 2007. Widespread mycorrhizal specificity correlates to mycorrhizal function in the neotropical, epiphytic orchid Ionopsis utricularioides (Orchidaceae). Amer. J. Bot. 94: 1944-1950.

Otero, J.T., C.P.H. Thrall, M. Clements, J.J. Burdon \& J.T. Miller. 2011. Codiversification of orchids 
(Pterostylidinae) and their associated mycorrhizal fungi. Austral. J. Bot. 59: 480-497.

Pereira, O.L., M.C.M. Kasuya, A.C. Borges \& E.F. Araújo. 2005a. Morphological and molecular characterization of mycorrhizal fungi isolated from neotropical orchids in Brazil. Canad. J. Bot. 83: 54-65.

Pereira, O.L., M.C.M. Kasuya, C.L. Rollemberg \& A.C. Borges. 2005b. In vitro symbiotic seed germination of Oncidium flexuosum (Orchidaceae) by Rhizoctonia-like mycorrhizal fungi. R. Bras. Ci. Solo. 29: 199-206.

Pérez-Hernández, H., A. Damon, J. Valle Mora \& D. Sánchez-Guillen. 2011. Orchid pollination: specialization in chance? Bot. J. Linn. Soc. 165: 251266.

Rains, K.C., N.M. Nadkarni \& C.S. Bledsoe. 2003. Epiphytic and terrestrial mycorrhizas in a lower montane Costa Rican cloud forest. Mycorrhiza 13: 257-264.

Rivas, R.M., J. Warner \& M. Bermúdez. 1998. Presencia de micorrizas en orquídeas de un jardín botánico neotropical. Rev. Biol. Trop. 46: 211-216.
Seaton, P. \& H. Pritchard. 2011. Orchid seed stores for sustainable use. Lankesteriana 11: 349-353.

Smith, S.E. \& D.J. Read. 1997. Mycorrhizal symbiosis. Academic Press, London.

Suárez, J.P., M. Weib, A. Abele, S. Garnica, F. Oberwinkler \& I. Kottke. 2006. Diverse tulasnelloid fungi form mycorrhizas with epiphytic orchids in an Andean cloud forest. Mycol. Res. 110: 1257-1270.

Waterman, R.J. \& M.I. Bidartondo. 2008. Deception above, deception below: linking pollination and mycorrhizal biology of orchids. J. Exp. Bot. 59: 1085-1096.

Zettler, L.W., T.W. Delaney \& J.A. Sunley. 1998. Seed propagation of the epiphytic green-fly orchid, Epidendrum conopseum R. Brown, using its endophytic fungus. Selbyana 19: 249-253.

Zettler, L.W., J. Sharma \& F.N. Rasmussen. 2003. Mycorrhizal diversity. Pp. 205-226 in: K.W. Dixon, S.P. Kell, R.L. Barrett, \& P.J. Cribb (eds.) Orchid conservation. Natural History Publications (Borneo), Kota Kinabalu, Sabah. 